\title{
CHYMASE-DEPENDENT ANGIOTENSIN II FORMATION IN THE SAPHENOUS VEIN VERSUS THE INTERNAL THORACIC ARTERY
}

\author{
Masayoshi Nishimoto, MD ${ }^{\mathrm{a}, \mathrm{b}}$ \\ Shinji Takai, $\mathrm{PhD}^{\mathrm{a}}$ \\ Yoshihide Sawada, MD $^{\mathrm{b}}$ \\ Atsushi Yuda, MD ${ }^{\mathrm{a}, \mathrm{b}}$ \\ Keiichiro Kondo, MD ${ }^{b}$ \\ Mayumi Yamada, $\mathrm{PhD}^{\mathrm{a}}$ \\ Denan Jin, MD \\ Masato Sakaguchi, $\mathrm{PhD}^{\mathrm{a}}$ \\ Kunio Asada, MD \\ Shinjiro Sasaki, MD ${ }^{\mathrm{b}}$ \\ Mizuo Miyazaki, MD
}

\begin{abstract}
Objectives: The great saphenous vein graft is known to be less patent than the internal thoracic artery graft. Recently, we reported that chymase-dependent angiotensin II formation plays an important role in the development of intimal hyperplasia in dog grafted veins. In this study we investigated the levels of angiotensin II-forming enzymes, angiotensin-converting enzyme, and chymase in human saphenous veins and internal thoracic arteries.
\end{abstract}

Methods: The saphenous vein and internal thoracic artery specimens were obtained from coronary artery bypass grafts of patients during surgical procedures (saphenous vein, $\mathrm{n}=16$; internal thoracic artery, $\mathrm{n}=16$ ). Activities of angiotensin-converting enzyme and chymase were determined by using the extract from the saphenous vein or internal thoracic artery. Sections of the saphenous vein or internal thoracic artery were stained with van Gieson's elastin stain and were immunostained with anti-human chymase antibody.

Results: The activities of angiotensin-converting enzyme in the saphenous vein and internal thoracic artery were $0.34 \pm 0.12$ and $0.32 \pm 0.17 \mathrm{mU} / \mathrm{mg}$ protein, respectively, and the difference was not significant. The chymase activity in the saphenous vein was significantly higher than that in the internal thoracic artery (saphenous vein, $10.1 \pm 0.81 \mathrm{mU} / \mathrm{mg}$ protein; internal thoracic artery, $6.21 \pm 1.86 \mathrm{mU} / \mathrm{mg}$ protein). Chymase-positive cells in the saphenous vein were located in both the media and adventitia, and those in the internal thoracic artery were located only in the adventitia. The number of chymase-positive cells in the saphenous vein was about 2.6 times that in the internal thoracic artery.

Conclusion: The chymase activity, but not the angiotensin-converting enzyme activity, was significantly higher in the saphenous vein, suggesting that the high levels of chymase activity may be related to the poorer performance of the saphenous vein for use as a bypass conduit. ( $\mathrm{J}$ Thorac Cardiovasc Surg 2001;121:729-34)
C oronary artery bypass grafting has offered patients with ischemic heart disease a significant improvement in longevity. ${ }^{1,2}$ The internal thoracic artery (ITA) and the saphenous vein (SV) are frequently used as coronary artery bypass conduits. However, the clinical

From the Department of Pharmacology a and the Department of Thoracic and Cardiovascular Surgery, ${ }^{\mathrm{b}}$ Osaka Medical College, Takatsuki City, Osaka, Japan.

Supported in part by Grant-in-Aid 12770048 for Encouragement of Young Scientists and Grant-in-Aid 11470027 for Scientific Research (B) from the Ministry of Education, Science, Sports and Culture, Japan.

Copyright (C) 2001 by The American Association for Thoracic Surgery

0022-5223/2001 $\$ 35.00+0 \quad \mathbf{1 2 / 1 / 1 1 2 4 6 7}$

doi: $10.1067 / \mathrm{mtc} .2001 .112467$ benefits are gradually lost and graft function deteriorates, resulting in recurrence of clinical symptoms. ${ }^{3-5}$ The poor performance of the SV in comparison to the ITA when used as a bypass conduit is widely known. ${ }^{3-5}$ Although early occlusions of the SV are thought to be chiefly caused by intimal hyperplasia, the mechanism of vascular proliferation remained unclear.

Angiotensin II plays an important role in vascular proliferation through the induction of growth factors and extracellular matrix, both of which participate in the first stages of the repair process. ${ }^{6-8}$ Borland and colleagues $^{9}$ reported that the contractile response of angiotensin II in isolated human SVs was greater than that in ITAs, suggesting that the SV exhibits greater angiotensin II-mediated action than the ITA. In graft 
experimental models an angiotensin-converting enzyme (ACE) inhibitor was effective in preventing vascular proliferation in rats, whereas it was not effective in baboons. ${ }^{10,11}$ Such species differences in the effects of ACE inhibitors on neointimal formation may depend on species differences in the angiotensin II-forming pathways. Rat vascular tissues contain $\mathrm{ACE}$ as the only angiotensin II-forming enzyme, whereas vascular tissues of humans, monkeys, dogs, and hamsters contain chymase in addition to ACE as angiotensin II-forming enzymes. ${ }^{12-15}$ Therefore, it is thought that ACE inhibitors could not suppress chymase-dependent angiotensin II formation, resulting in vascular proliferation in primate vessels, despite the prevention of such proliferation in rats. Recently, we demonstrated that a chymase inhibitor prevents vascular proliferation in dog grafted veins. ${ }^{16}$ This finding suggests that the chymase may play an important role in the development of vascular proliferation in grafted veins.

In the present study we investigated the levels of the angiotensin II-forming enzymes, ACE and chymase, and the distribution of chymase-positive cells in human SVs and ITAs.

\section{Methods}

Human vessels. ITA and SV specimens were obtained from 16 patients who underwent coronary artery bypass surgery (14 men and 2 women; age range, 48-80 years). No patients received ACE-inhibition therapy before their operations. All subjects gave written consent after a full explanation of the purpose of this study. The protocol of this study complied with the principles of the Helsinki Declaration.

Preparation of vascular tissue. The ITA or SV specimens were minced and homogenized in 10 volumes (wt/vol) of 20 $\mathrm{mmol} / \mathrm{L}$ Na-phosphate buffer ( $\mathrm{pH}$ 7.4). The homogenate was centrifuged at $20,000 \mathrm{~g}$ for 30 minutes. The supernatant was discarded, and the pellet was resuspended and homogenized in 5 volumes (wt/vol) of $10 \mathrm{mmol} / \mathrm{L} \mathrm{Na}$-phosphate buffer ( $\mathrm{pH}$ 7.4), containing $2 \mathrm{~mol} / \mathrm{L} \mathrm{KCl}$ and $0.1 \%$ Nonidet P-40. The homogenate was stored overnight at $4^{\circ} \mathrm{C}$ and centrifuged at $20,000 \mathrm{~g}$ for 30 minutes. The supernatant was used for measurement of the ACE and chymase activities.

Measurement of enzyme activities. The ACE activity was measured with a synthetic substrate, hippuryl-His-Leu, specifically designed for ACE (Peptide Institute Inc, Osaka, Japan). Fifty microliters of tissue extract or plasma was incubated for 30 minutes at $37^{\circ} \mathrm{C}$ with $5 \mathrm{mmol} / \mathrm{L}$ hippuryl-HisLeu in $250 \mu \mathrm{L}$ of $10 \mathrm{mmol} / \mathrm{L}$ phosphate buffer ( $\mathrm{pH} 8.3$ ), containing $600 \mathrm{mmol} / \mathrm{L} \mathrm{NaCl} .{ }^{17,18}$ The reaction was terminated by addition of $750 \mu \mathrm{L}$ of $3 \%$ metaphosphoric acid, and then the mixture was centrifuged at $20,000 \mathrm{~g}$ for 5 minutes at $4^{\circ} \mathrm{C}$. The supernatant was applied to a reversed-phase column (4 $\mathrm{mm}$ intradermally $\times 250 \mathrm{~mm}$; IRICA Instrument, Kyoto, Japan), which had been equilibrated with $10 \mathrm{mmol} / \mathrm{L}$
$\mathrm{KH}_{2} \mathrm{PO}_{4}$ and $\mathrm{CH}_{3} \mathrm{OH}(1: 1, \mathrm{pH} 3.0)$ and eluted with the same solution at a rate of $0.3 \mathrm{~mL} / \mathrm{min} .{ }^{17,18}$ Hippuric acid was detected by using ultraviolet absorbance at $228 \mathrm{~nm}$. One unit of ACE activity was defined as the amount of enzyme that cleaved $1 \mu \mathrm{mol} / \mathrm{L}$ of hippuric acid per minute.

The chymase activity was measured by incubating tissue extracts for 30 minutes at $37^{\circ} \mathrm{C}$ with $770 \mu \mathrm{mol} / \mathrm{L}$ angiotensin $\mathrm{I}$ in $150 \mathrm{mmol} / \mathrm{L}$ borax-borate buffer ( $\mathrm{pH} 8.5)$, containing $8 \mathrm{mmol} / \mathrm{L}$ dipyridyl, $770 \mu \mathrm{mol} / \mathrm{L}$ di-isopropyl fluorophosphate, and $5 \mathrm{mmol} / \mathrm{L}$ ethylenediamine tetraacetic acid, as described previously. ${ }^{12,18}$ The reaction was terminated by addition of $15 \%$ trichloroacetic acid, and then the mixture was centrifuged at $20,000 \mathrm{~g}$ for 5 minutes at $4^{\circ} \mathrm{C}$. For fluorometric quantitation of His-Leu formed from an angiotensin I substrate, 10\% o-phthaldialdehyde (dissolved in methanol) was added to the supernatant in the alkaline state and was incubated for 10 minutes at room temperature. Reaction was terminated by addition of $6 \mathrm{~mol} / \mathrm{L} \mathrm{HCl}$, and the fluorescence was measured at $340 \mathrm{~nm}$ excitation and $455 \mathrm{~nm}$ emission. One unit of chymase activity was defined as the amount of enzyme that cleaved $1 \mu \mathrm{mol}$ of His-Leu per minute. A blank was also included (ie, the addition of 500 $\mathrm{mmol} / \mathrm{L}$ chymostatin).

The total angiotensin II-forming activity was measured by incubating tissue extracts for 30 minutes at $37^{\circ} \mathrm{C}$ with 1 $\mathrm{mmol} / \mathrm{L}$ angiotensin $\mathrm{I}$ in $20 \mathrm{mmol} / \mathrm{L}$ Tris- $\mathrm{HCl}$ buffer containing $0.1 \%$ Triton $\mathrm{X}-100(\mathrm{pH} 8.5)$. The reaction was terminated by addition of $15 \%$ trichloroacetic acid, and then the mixture was centrifuged at $20,000 \mathrm{~g}$ for 5 minutes at $4{ }^{\circ} \mathrm{C}$. The supernatant was applied to a reversed-phase column (ODS 80-Tm, $4.6 \mathrm{~mm}$ intradermally $\times 250 \mathrm{~mm}$; Tohso, Yamaguchi, Japan), which had been equilibrated with $30 \% \mathrm{CH}_{3} \mathrm{OH}$ in $10 \mathrm{mmol} / \mathrm{L}$ phosphoric acid and eluted with a linear gradient of $30 \%$ to $90 \% \mathrm{CH}_{3} \mathrm{OH}$ in 10 $\mathrm{mmol} / \mathrm{L}$ phosphoric acid at a rate of $1 \mathrm{~mL} / \mathrm{min}$. The angiotensin II concentration was detected by using ultraviolet absorbance at $226 \mathrm{~nm}$ and was determined as the quantity of angiotensin II formed per minute. ${ }^{19}$

Protein concentration was assayed with BCA Protein Assay Reagents (Pierce, Rockford, Ill) by using bovine serum albumin as a standard.

Histologic analysis. The ITA or SV segments were fixed in $10 \%$ methanol-Carnoy fixative overnight and embedded in paraffin. The sections were cut from each block at $3-\mu \mathrm{m}$ thickness. The sections were stained with hematoxylin-eosin and van Gieson elastin stain, respectively.

The other sections were used for immunohistochemical staining. The primary antibody for anti-human chymase used in the present study was the following: mouse anti-human chymase monoclonal immunoglobulin G (1:1000 dilution; Chemicon International Inc, Temecula, Calif). Immunohistochemical staining was performed with an avidin-biotinperoxidase kit (Dako LSAB kit; DAKO Corporation, Carpinteria, Calif) with 3-amino-9-ethylcarbazole color development. As a negative control, the primary antibody was omitted and replaced by an equal concentration of nonimmune mouse monoclonal immunoglobulin G. 

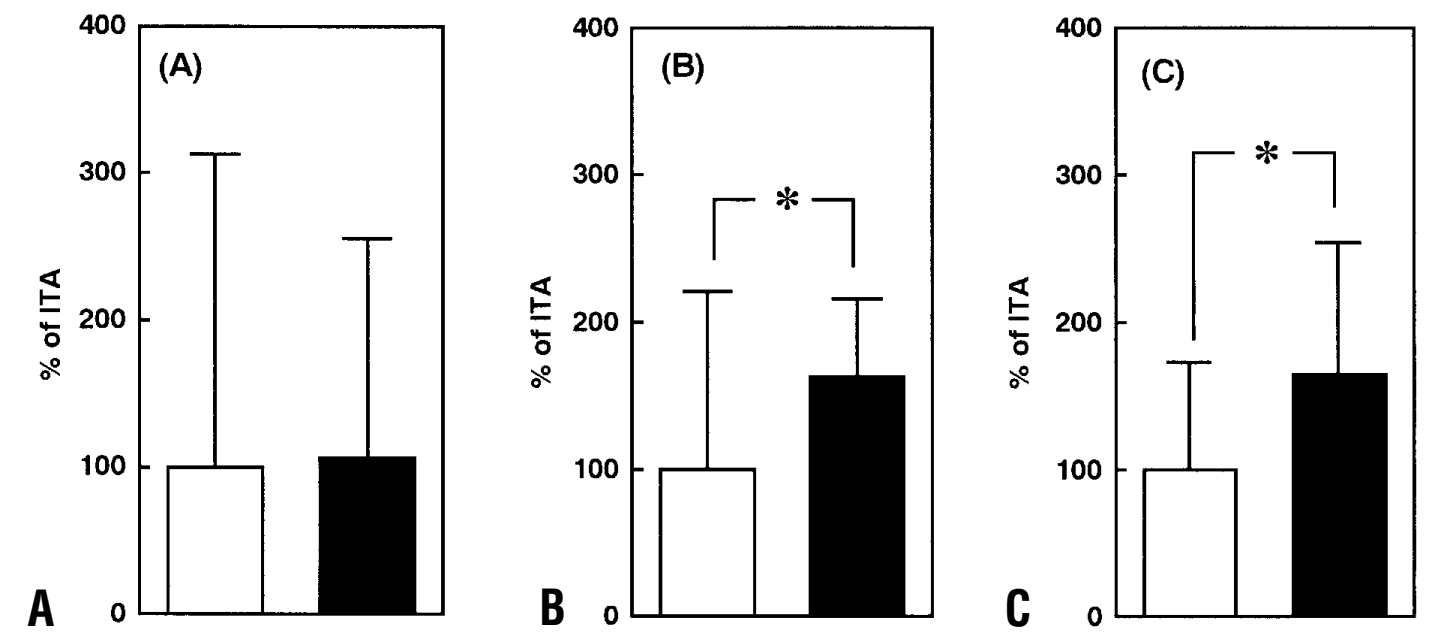

Fig 1. ACE (A), chymase (B), and total angiotensin II-forming activities (C) in the ITA (open column) and SV (closed column). Activity of each enzyme in the ITA was regarded as $100 \%$. $* P<.05$ versus ITA.

The number of chymase-positive cells was quantified with an image-analysis system (VM-30; Olympus Optical Co, Tokyo, Japan).

Statistical analysis. All data shown in the text were expressed as means \pm SD. Data were analyzed by using the 2-tailed Student $t$ test for paired observations.

\section{Results}

Enzyme activities in ITA and SV. The ACE activity in the ITA was $0.32 \pm 0.68 \mathrm{mU} / \mathrm{mg}$ protein, whereas that in the $\mathrm{SV}$ was $0.34 \pm 0.48 \mathrm{mU} / \mathrm{mg}$ protein, and this difference was not significant. The chymase activity in the ITA was $6.21 \pm 7.44 \mathrm{mU} / \mathrm{mg}$ protein, whereas that in the $\mathrm{SV}$ was $10.1 \pm 3.24 \mathrm{mU} / \mathrm{mg}$ protein, and this difference was significant $(P=.045)$. When the activity of each enzyme in the ITA was regarded as $100 \%$, the ACE and chymase activities in the SV were $106.3 \%$ and $162.6 \%$, respectively (Fig $1, A$ and $B$ ). The total angiotensin II-forming activity was also increased in the SV compared with the ITA (ITA, $4.57 \pm 3.28$ $\mathrm{mU} / \mathrm{mg}$ protein; $\mathrm{SV}, 7.47 \pm 4.16 \mathrm{mU} / \mathrm{mg}$ protein), and the ratio of the SV to the ITA was $163.5 \%$ (Fig 1, C). This difference was also significant $(P=.01)$.

Histochemical study in SV and ITA. Immunostaining with an antibody to human chymase localizes this enzyme to the medial and adventitial layers in the $\mathrm{SV}$, whereas in the ITA immunostaining reveals the enzyme only in the adventitial layer (Fig 2). The number of chymase-positive cells in the SV was $8.80 \pm 1.72$ cells $/ \mathrm{mm}^{2}$, whereas that in the ITA was $3.36 \pm 3.23$ cells $/ \mathrm{mm}^{2}$ (Fig 3), and this difference was significant $(P=.0001)$.

\section{Discussion}

In this study we demonstrated that the chymase activity, but not the ACE activity, was significantly higher in the SV than in the ITA. The ratio of chymase activity in the SV to that in the ITA was $162.6 \%$, and the total angiotensin II-forming activity was $163.5 \%$ in the SV. This high level of total angiotensin II-forming activity in the SV is thought to be dependent on the upregulated chymase activity. The number of chymase-positive cells in the SV was significantly higher than in the ITA. In particular, the chymase-positive cells were observed in the medial layer only in the SV. In general, chymase is widely known to be contained only in mast cells, ${ }^{20,21}$ and the chymase-positive cells were also identified as the mast cells in this study (data not shown). Therefore the number of chymase-positive mast cells in the SV was higher than that in the ITA, resulting in the high level of angiotensin II-forming activity by the upregulated chymase activity in the SV.

Previously, Borland and colleagues ${ }^{9}$ reported that the angiotensin II-induced vascular contraction in isolated human SV was greater than that in the ITA and that the responses were mediated through the angiotensin type $1\left(\mathrm{AT}_{1}\right)$ receptor but not through the $\mathrm{AT}_{2}$ receptor. The greater action of angiotensin II through the $\mathrm{AT}_{1}$ receptor in the SV may potentiate the development of vascular hyperplasia. On the other hand, it has been reported that ITA and SV contain chymase as an angiotensin II-forming enzyme. ${ }^{22,23}$ However, the levels of ACE and chymase in the SV or ITA remained unclear. In this study we demonstrated for the first time that the angiotensin II-forming activity by chymase, but not by 

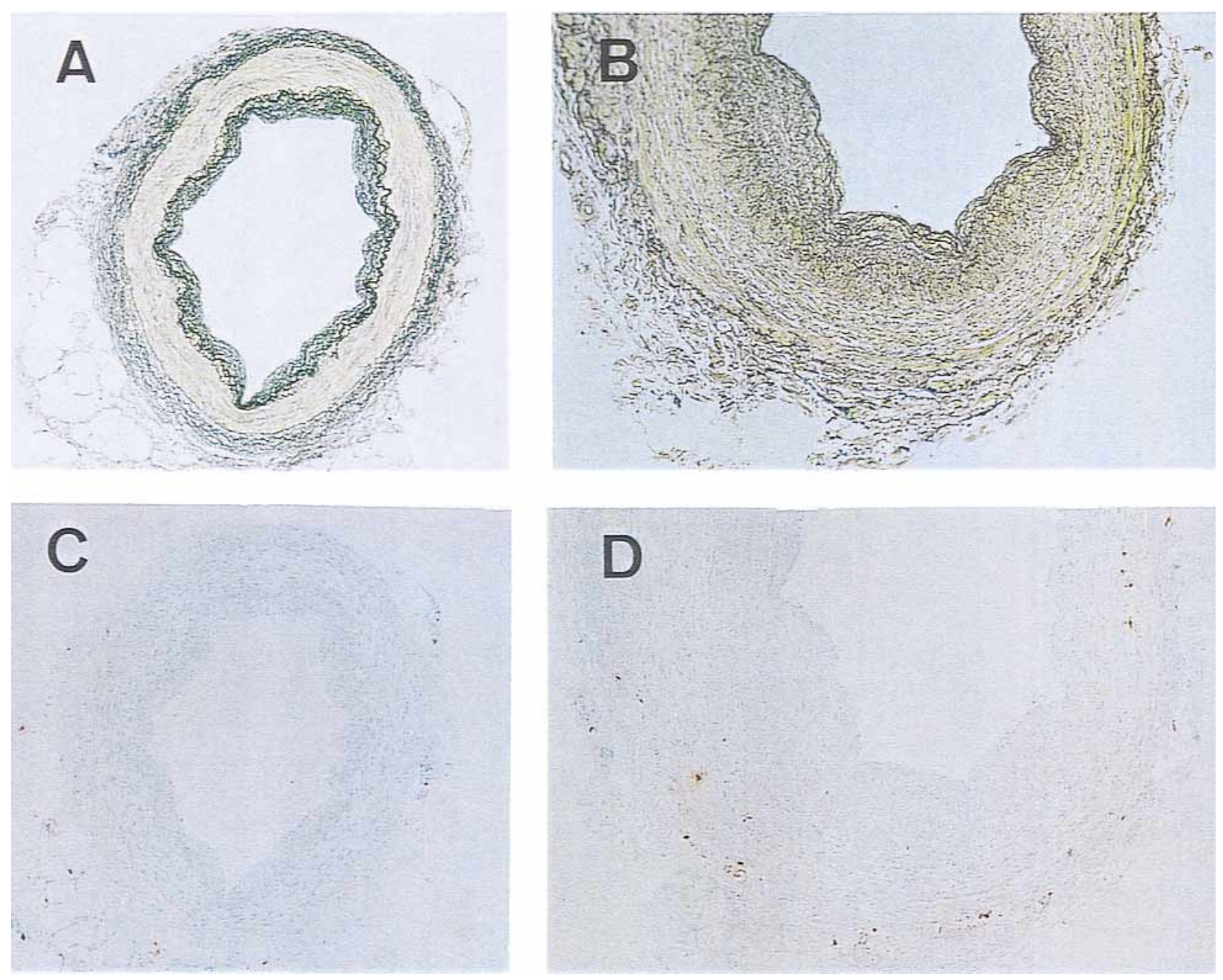

Fig 2. Sections (3 $\mu \mathrm{m}$ each) from the ITA (A) and SV (B) were stained with van Gieson elastin stain. For immunohistochemical analysis, sections (3 $\mu \mathrm{m}$ each) from the ITA (C) and SV (D) were performed with an antibody for human chymase and were performed by using an avidin-biotin-peroxidase kit with 3-amino-9-ethylcarbazole color development. (Original magnification, 35×.)

ACE, was increased in the SV compared with the ITA. The high level of angiotensin II-forming activity caused by chymase, in addition to the activated angiotensin II-induced response, may play a crucial role in vascular hyperplasia.

In the dog graft model we reported that ACE and chymase activities in the grafted veins were significantly increased 2- and 15-fold, respectively, compared with untreated veins 28 days after the grafting. ${ }^{19}$ The ACE and chymase activities in the grafted veins were activated after grafting, and angiotensin II-forming activity through chymase was especially accelerated, suggesting that the activated angiotensin II formation by means of chymase may be important in the development of vascular proliferation. In fact, in this model the vascular proliferation was suppressed by a chymase inhibitor. ${ }^{19}$ It is reported that chymase, an enzyme that is present in mast cell granules, is released from the granules on strong stimulation, such as in injured vessels after grafting, and then mast cells accumulate. ${ }^{20,21}$ Although chymase is known to activate angiotensin I to angiotensin II, it also activates stem cell factor, a typical cytokine that has the ability to induce accumulation of mast cells. In this study the level of chymase in the SV was higher than that in the ITA. After grafting, the high number of chymase-positive mast cells in the SV may easily induce the additional accumulation of mast cells through the activation of stem cell factor by chymase. In fact, in a dog model the number of mast cells and chymase activity were increased in the grafted 
veins, whereas chymase inhibitor suppressed not only chymase activity but also the number of mast cells. ${ }^{19}$ Moreover, the chymase-positive mast cells were observed in the medial layer only in the SV. Cytokines activated by chymase in the medial layer, such as stem cell factor, which is filled with smooth muscle cells (SMCs), may induce an increase in chymase-positive mast cells in the SMCs. The proliferation of SMCs is an important component of vascular hyperplasia, and angiotensin II plays a key role in regulating the growth of vascular SMCs. ${ }^{24}$ The increase of chymase-dependent angiotensin II formation in the medial layer of the SV may be involved in the growth of SMCs.

In a clinical study restenosis after percutaneous transluminal coronary angioplasty was prevented by a degranulating inhibitor for mast cells, tranilast. ${ }^{25}$ Although tranilast has been widely used for the clinical treatment of bronchial asthma and atopic dermatitis, ${ }^{26,27}$ its mechanism of preventive effect in restenosis after percutaneous transluminal coronary angioplasty has been unclear. Recently, we demonstrated that tranilast prevented vascular hyperplasia in a balloon injury dog model. ${ }^{28}$ In this model both the number of mast cells and chymase activity were increased in the vessels injured by a balloon catheter 30 days after the injury, whereas the treatment of tranilast inhibited not only the accumulation of mast cells but also the increased chymase activity. These findings suggest that accumulation of chymase-positive mast cells is closely related to vascular hyperplasia.

In later occlusion, intimal hyperplasia after coronary artery bypass grafting may be due to the development of atherosclerosis. Previously, we demonstrated that chymase, ACE, and angiotensin II concentration were significantly increased in the atherosclerotic lesions in monkeys fed a high-cholesterol diet. ${ }^{29,30}$ In this model angiotensin II receptor antagonist significantly suppressed the atherosclerotic area. ${ }^{29}$ These findings suggest that increased angiotensin II levels play an important role in the development of atherosclerosis. In this study the angiotensin II-forming activity was increased in the SV, and the high levels of angiotensin II-forming ability in the SV may also induce the intimal hyperplasia.

In conclusion, we demonstrated that angiotensin II-forming activity through chymase in the SV was higher than that in the ITA, and the chymase-positive mast cells in the medial layer may play an important role in the development of vascular hyperplasia in the SV used as a graft conduit.

Received for publication May 4, 2000; revisions requested Aug 22, 2000; revisions received Oct 10, 2000; accepted for publication Oct 10, 2000.

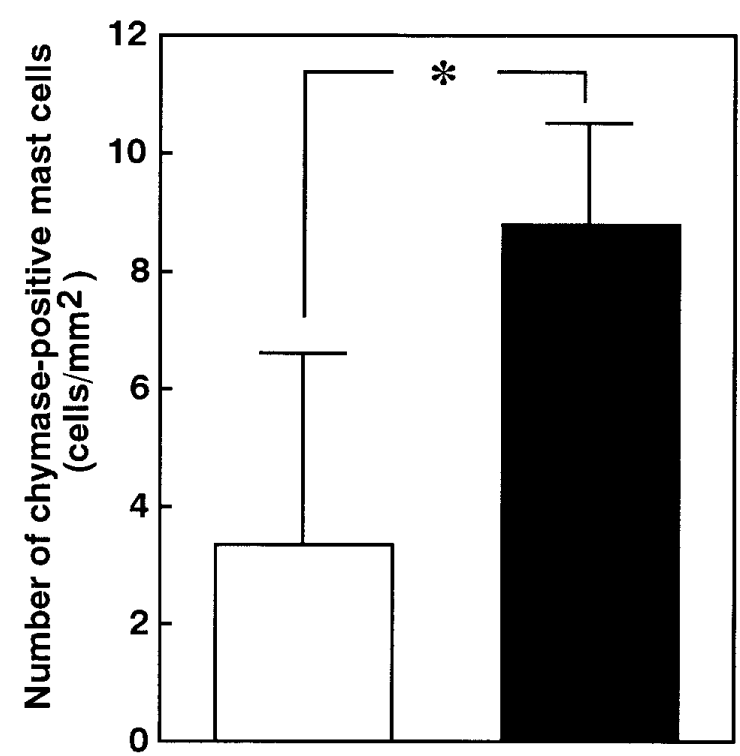

Fig 3. Number of chymase-positive mast cells in the ITA (open column) and SV (closed column). $* P<.05$ versus ITA.

Address for reprints: Mizuo Miyazaki, MD, PhD, Department of Pharmacology, Osaka Medical College, 2-7 Daigaku-cho, Takatsuki City, Osaka 569-8686, Japan.

\section{REFERENCES}

1. Green GE, Stertzer SH, Reppert EH. Coronary arterial bypass grafts. Ann Thorac Surg 1968;5:443-50.

2. Urschel HC, Miller ER, Razzuk MA, Alvares JF, McNamara JJ, Paulson DL. Aorta-to-coronary-artery vein bypass graft for coronary artery occlusive disease. Ann Thorac Surg 1969;8:114-25.

3. Fuchs JC, Mitchener JS, Hagen PO. Postoperative changes in autologous vein grafts. Ann Surg 1978;188:1-15.

4. Lytle BW, Loop FD, Cosgrove DM, Ratliff NB, Easley K, Taylor PC. Long-term (5 to 12 years) serial studies of internal mammary artery and saphenous vein coronary bypass grafts. J Thorac Cardiovasc Surg 1985;89:248-58.

5. Lytle BW, Loop FD, Taylor PC, Simpfendorfer C, Kramer JR, Ratliff NB, et al. Vein graft disease: the clinical impact of stenoses in saphenous vein bypass grafts to coronary arteries. J Thorac Cardiovasc Surg 1992;103:831-40.

6. Majesky MW, Lindner V, Twardzik DR, Schwartz SM, Reidy MA. Production of transforming growth factor beta 1 during repair of arterial injury. J Clin Invest 1991;88:904-10.

7. Kim S, Kawamura M, Wanibuchi H, Ohta K, Hamaguchi A, Omura T, et al. Angiotensin II type 1 receptor blockade inhibits the expression of immediate-early genes and fibronectin in rat injured artery. Circulation 1995;92:88-95.

8. Nikol S, Huehns TY, Hofling B. Molecular biology and postangioplasty restenosis. Atherosclerosis 1996;123:17-31.

9. Borland JA, Chester AH, Crabbe S, Parkerson JB, Catravas JD, Yacoub MH. Differential action of angiotensin II and activity of angiotensin-converting enzyme in human bypass grafts. J Thorac Cardiovasc Surg 1998;116:206-12.

10. Roux SP, Clozel JP, Kuhn H. Cilazapril inhibits wall thickening of vein bypass graft in the rat. Hypertension 1991;18(Suppl 4):II43-6. 
11. Hanson SR, Powell JS, Dodson T, Lumsden A, Kelly AB, Anderson JS, et al. Effects of angiotensin converting enzyme inhibition with cilazapril on intimal hyperplasia in injured arteries and vascular grafts in the baboon. Hypertension 1991;18(Suppl 4):II70-6.

12. Okunishi H, Miyazaki M, Okamura T, Toda N. Different distribution of two types of angiotensin II-generating enzymes in the aortic wall. Biochem Biophys Res Commun 1987;149:1186-92.

13. Takai S, Shiota N, Sakaguchi M, Muraguchi H, Matsumura E, Miyazaki M. Characterization of chymase from human vascular tissues. Clin Chim Acta 1997;265:13-20.

14. Takai S, Shiota N, Kobayashi S, Matsumura E, Miyazaki M. Induction of chymase that forms angiotensin II in the monkey atherosclerotic aorta. FEBS Lett 1997;412:86-90.

15. Takai S, Shiota N, Yamamoto D, Okunishi H, Miyazaki M. Purification and characterization of angiotensin II-generating chymase from hamster cheek pouch. Life Sci 1996;58:591-7.

16. Takai S, Yuda A, Jin D, Nishimoto M, Sakagichi M, Sasaki S, et al. Inhibition of chymase reduces vascular proliferation in dog grafted veins. FEBS Lett 2000;467:141-4.

17. Miyazaki M, Okunishi H, Nishimura K, Toda N. Vascular angiotensin-converting enzyme activity in man and other species. Clin Sci 1984;66:39-45.

18. Jin D, Takai S, Shiota N, Miyazaki M. Roles of vascular angiotensin converting enzyme and chymase in two-kidney, one clip hypertensive hamsters. J Hypertens 1998;16:657-64.

19. Takai S, Jin D, Sakaguchi M, Miyazaki M. Chymase-dependent angiotensin II formation in human vascular tissue. Circulation 1999; 100:654-8.

20. Schwartz LB, Austen KF. Enzymes of the mast cell granule. J Invest Dermatol 1980;74:349-53.

21. Schwartz LB. Mediators of human mast cells and human mast cell subsets. Ann Allergy 1987;58:226-35.
22. Borland JA, Chester AH, Morrison KA, Yacoub MH. Alternative pathways of angiotensin II production in the human saphenous vein. Br J Pharmacol 1998;125:423-8.

23. Voors AA, Pinto YM, Buikema H, Urata H, Oosterga M, Rooks $\mathrm{G}$, et al. Dual pathway for angiotensin II formation in human internal mammary arteries. Br J Pharmacol 1998;125:1028-32.

24. Daemen MJ, Lombardi DM, Bosman FT, Schwartz SM. Angiotensin II induces smooth muscle cell proliferation in the normal and injured rat arterial wall. Circ Res 1991;68:450-6.

25. Tamai H, Katoh O, Suzuki S, Fujii K, Aizawa T, Takase S, et al. Impact of tranilast on restenosis after coronary angioplasty: tranilast restenosis following angioplasty trial (TREAT). Am Heart J 1999;138:968-75.

26. Azuma H, Banno K, Yoshimura T. Pharmacological properties of $N$-(3',4'-dimethoxycinnamoyl) anthranilic acid $\left(N-5^{\prime}\right)$, a new anti-atopic agent. Br J Pharmacol 1976;58:483-8.

27. Komatsu H, Kojima M, Tsutsumi N, Hamano S, Kusama H, Ujiie A, et al. Study of the mechanism of inhibitory action of tranilast on chemical mediator release. Jpn J Pharmacol 1988;46:43-51.

28. Shiota N, Okunishi H, Takai S, Mikoshiba I, Sakonjo H, Shibata $\mathrm{N}$, et al. Tranilast suppresses vascular chymase expression and neointima formation in balloon-injured dog carotid artery. Circulation 1999;99:1084-90.

29. Miyazaki M, Sakonjo H, Takai S. Anti-atherosclerotic effects of an angiotensin converting enzyme inhibitor and an angiotensin II antagonist in Cynomolgus monkeys fed a high-cholesterol diet. Br J Pharmacol 1999;128:523-9.

30. Song K, Shiota N, Takai S, Takashima H, Iwasaki H, Kim S, et al. Induction of angiotensin converting enzyme and angiotensin II receptors in the atherosclerotic aorta of high-cholesterol fed Cynomolgus monkeys. Atherosclerosis 1998;138:171-82.

\section{Bound volumes available to subscribers}

Bound volumes of The Journal of Thoracic and Cardiovascular Surgery are available to subscribers (only) for the 2001 issues from the Publisher, at a cost of \$134.00 for domestic, \$165.85 for Canadian, and \$155.00 for international subscribers for Vol 121 (January-June) and Vol 122 (July-December). Shipping charges are included. Each bound volume contains a subject and author index and all advertising is removed. Copies are shipped within 60 days after publication of the last issue of the volume. The binding is durable buckram with the Journal name, volume number, and year stamped in gold on the spine. Payment must accompany all orders. Contact Mosby, Subscription Customer Service, 6277 Sea Harbor Dr, Orlando, FL 32887,USA; phone 800-654-2452 or 407-345-4000.

Subscriptions must be in force to qualify. Bound volumes are not available in place of a regular Journal subscription. 